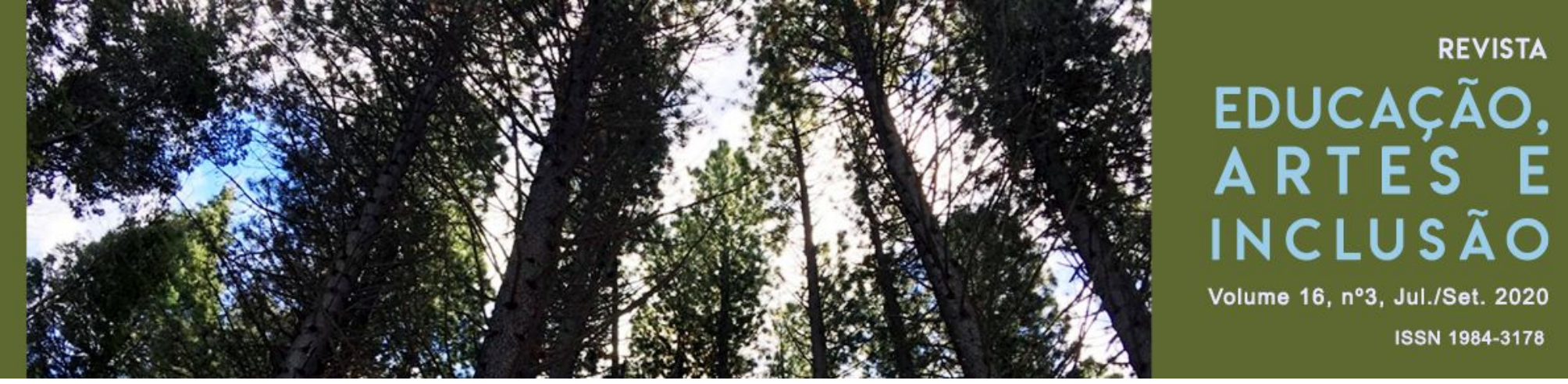

\title{
Uma proposta à leitura de imagens por pessoas com deficiência visual
}

\section{Una propuesta de lectura de imágenes por personas con discapacidad visual}

DOI: http://dx.doi.org/10.5965/198431781632020291

\author{
Andressa Dias Koehler \\ Universidade Federal do Espírito Santo \\ andressadk@gmail.com | ORCID
}

Gerda Margit Schütz

Universidade Federal do Espírito Santo gerda foerste@yahoo.com.br | ORCID

\section{RESUMO}

Este texto discute os impactos que as barreiras comunicacionais presentes em produtos audiovisuais não acessíveis podem causar a pessoas com deficiência visual em situações comunicativas diversas. Relata e analisa uma experiência com grupo focal desenvolvida em um instituto de cegos do Espírito Santo, com a apresentação de imagens dinâmicas e estáticas em duas condições: com e sem audiodescrição. Tece reflexões sobre a importância das imagens sob a ótica de Schütz-Foerste (2004), Ciavatta (2012), Koehler (2017) Wulf (2013), Sacks (2010), Bakhtin (2003), dentre outros autores. Conclui que a ausência de audiodescrição em produtos audiovisuais impõe limitações à formação de leitores com deficiência visual no que diz respeito aos textos imagéticos, comprometendo a leitura de imagens como intertexto, representação e fonte histórica, o que influencia diretamente na construção identitária desses sujeitos. Ademais, a escassa experiência com processos miméticos que remetem a produtos, cenas, arranjos e representações históricas e culturais, por parte desse público, pode limitar ainda a aquisição e a transmissão de bens culturais entre gerações de pessoas do mesmo contexto.

Palavras-chave: Deficiência visual. Audiodescrição. Acessibilidade. Barreiras comunicacionais.

\section{RESUMEN}

Este documento analiza los impactos que las barreras de comunicación presentes en productos audiovisuales no accesibles pueden tener en personas con discapacidad visual en diferentes situaciones comunicativas. Informar y analizar una experiencia de grupo focal desarrollada en un instituto ciego de Espírito Santo, con la presentación de imágenes dinámicas y estáticas en dos condiciones: con y sin descripción de audio. Reflexiona sobre la importancia de las imágenes desde la perspectiva de Schütz-Foerste (2004), Ciavatta (2012), Koehler (2017) Wulf (2013), Sacks (2010), Bakhtin (2003), entre otros autores. Concluye que la ausencia de audiodescripción en productos audiovisuales impone 


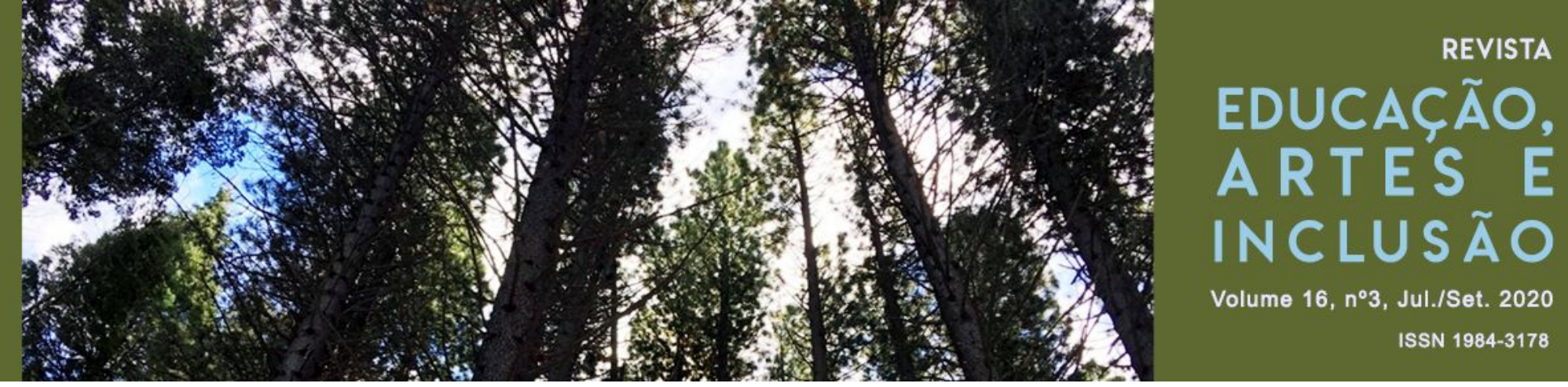

limitaciones en la formación de lectores con discapacidad visual con respecto a los textos de imagen, comprometiendo la lectura de imágenes como intertexto, representación y fuente histórica, lo que influye directamente en la construcción de identidad de estas personas. Además, la escasa experiencia con procesos miméticos que se refieren a productos, escenas, arreglos y representaciones históricas y culturales de este público también puede limitar la adquisición y transmisión de bienes culturales entre generaciones de personas del mismo contexto.

Palabras clave: Discapacidad visual. Descripción de audio. Accesibilidad. Barreras de comunicación.

\section{PENSANDO A INCLUSÃO NO CONTEXTO DE UMA SOCIEDADE IMAGÉTICA}

Costuma-se até dizer que não há cegueiras, mas cegos, quando a experiência dos tempos não tem feito outra coisa que dizer-nos que não há cegos, mas cegueiras.

José Saramago

Em um contexto social permeado pelas imagens, atribui-se a elas uma capacidade potencializadora do processo de ensino-aprendizagem. De acordo com Camargo (2007, p. 112), as imagens "(...) passaram a ser narrativa do mundo, estabelecendo diálogos com o mundo e não [apenas] as representações dele". Não raramente professores recorrem a charges, fotografias, gráficos, imagens artísticas, documentários, filmes e slides para apresentar conteúdos de maneira mais interativa e ilustrada.

Em situações educativas, muito se fala de educar o olhar para a leitura de imagens, em um movimento circular de autor-obra-leitor, afinal, a leitura de imagens também passa por um processo de aprendizagem. Sobre isso, Schütz-Foerste considera que "A alfabetização estético-visual do cidadão se coloca, hoje, como uma necessidade", pois "o homem contemporâneo é desafiado a ler mensagens visuais num mundo predominantemente perpassado pela mídia e pelas imagens" (SCHÜTZ-FOERSTE, 2004, p. 15). A autora atenta ainda para o fato de que "a partir da nova realidade técnico-produtiva, o discurso traz a exigência de que o profissional 


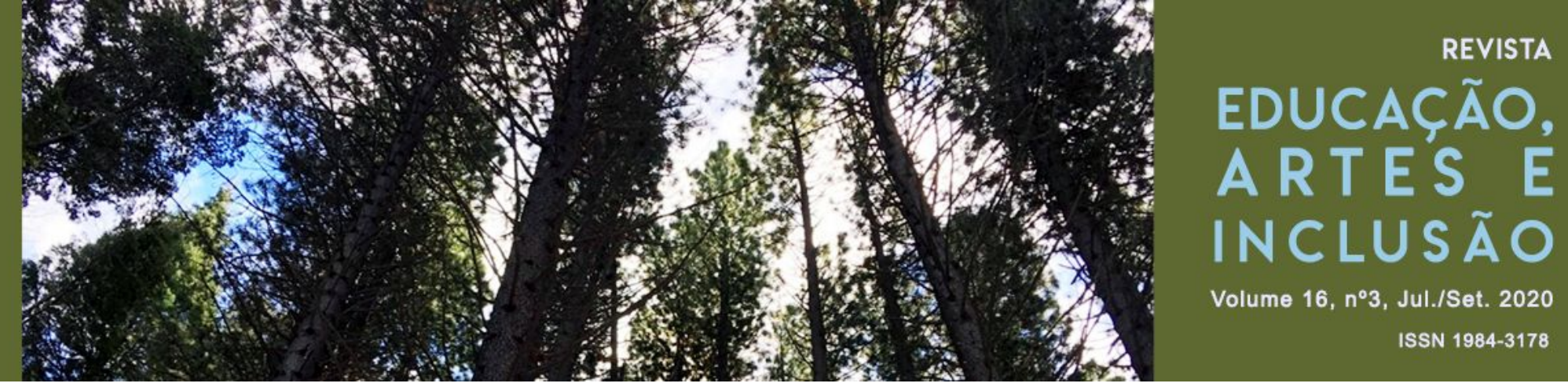

seja capaz de analisar, interpretar e intervir criativamente resolvendo situações inusitadas" (SCHÜTZ-FOERSTE, 2004, p. 15).

Em acordo com Bakhtin quanto à comunicação em sentido dialógico, o agente do diálogo "[...] como sujeito e permanecendo como sujeito, não pode tornar-se mudo; consequentemente, o conhecimento que se pode ter dele só pode ser dialógico" (BAKHTIN, 2003, p. 400). Nesse viés, o sujeito leitor não é um ser passivo diante do que lê, mas um agente que se transforma, porque responde semanticamente ao objeto, seja um poema, uma canção, uma pintura ou imagem de um produto audiovisual. Há, nesse processo de leitura, um encontro de subjetividades entre leitor, obra, autor e tantas outras vozes que perpassam essas subjetividades. E essa leitura, num sentido plural, pressupõe uma diversidade de expressões e linguagens, a partir da combinação entre palavra, imagem e som, como ocorre nos produtos audiovisuais e nas artes.

Conforme afirmou Martine Joly (2006, p.136) em seu livro "Introdução à análise da imagem", "interessar-se pela imagem é também interessar-se por toda a nossa história. É inegável que, em uma sociedade tão midiática, grande parte das informações nos adentram pela visão, nosso sentido predominante.

Esse fato, todavia, apesar da magnificência que representa nos estudos sobre as diferentes linguagens, também desperta nosso olhar, enquanto educadores e sujeitos sociais, para um diálogo entre educação visual e inclusão. Em meio ao discurso de que aprendemos melhor por meio das imagens, há que considerarmos que alguns sujeitos não têm acesso a essas por meio da visão, mas por caminhos alternativos que precisam ser pensados tanto no contexto escolar quanto nas situações de lazer, marketing ou de informação pública. Nesse grupo, se enquadram as pessoas com deficiência visual - cegueira ou baixa-visão.

Cabe destacar que, segundo dados do censo demográfico o Instituto Brasileiro de Geografia e Estatística (IBGE, 2010), no Brasil, das mais de 6,5 


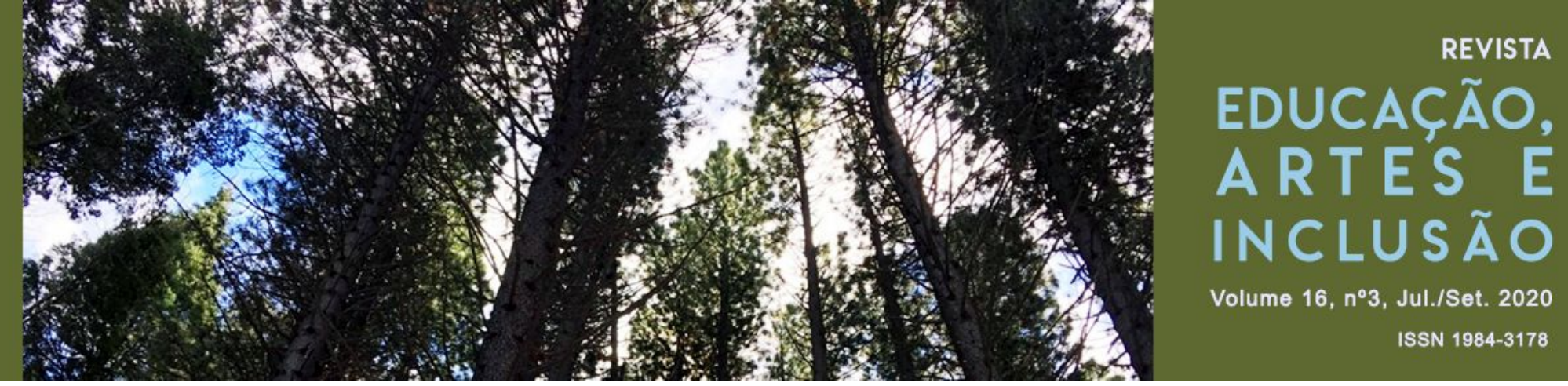

milhões de pessoas com alguma deficiência visual, 528.624 pessoas são incapazes de enxergar, enquanto 6.056.654 pessoas possuem baixa visão. Durante muitos anos, essas pessoas estiveram alijadas da educação escolar formal e também de um projeto de sociedade no qual atuassem como cidadãs participantes.

Lúcia Reily, em "Músicos cegos ou cegos músicos: representações de compensação sensorial na história da arte" (2008), fez uma análise da figura de músicos cegos à luz de representações de cegos instrumentistas em obras da História da Arte, mostrando a fragilidade do lugar social ocupado pelo esses indivíduos que carregam historicamente "a bagagem do assistencialismo, da marginalidade e da miséria, por um lado, e do mito da superação do infortúnio e da compensação da perda visual pela hipersensibilidade auditiva de outro" (REILY, 2008, p. 246). Um dos apontamentos feitos por Reily após esse estudo foi o de que

Os temas miséria e mendicância são constantes nos retratos dos cegos músicos da Era Cristã. Rembrandt van Rijn, Pablo Picasso, Georges de La Tour e vários outros utilizam a coloração sombria, a composição de figura em primeiro plano, com a postura de ombros caídos, a expressão triste do rosto, para falar da condição precária desta figura urbana, cujo trabalho é ao mesmo tempo ganha-pão e manifestação de súplica. A dualidade esperança desesperança também é expressa simbolicamente, principalmente a partir dos artistas do Romantismo. John Everett Millais, pintor romântico inglês, desenvolveu diversos estudos sobre a menina cega nos quais a temática em questão ganha uma dimensão moralizante, de lição de vida. No famoso quadro de Millais, a jovem cega está com sua sanfona no colo; a cabeça erguida permite que seu rosto tranqüilo seja iluminado pelo sol que saiu por detrás das nuvens, agora que a chuva passou. A pista é o arco-íris no alto do quadro sobre um céu ainda escurecido pela chuva que agora se distancia. A criança que acompanha a cega se volta para olhar para este sinal de esperança. Mas a cega tem outros meios de saber que o sol saiu, que a vida pode ser boa, pois ela sente o calor no próprio rosto (REILY, 2008, p. 259).

Assim, reconhecendo a importância das imagens em nossa sociedade e, em particular, no ambiente escolar, e também cientes da importância do protagonismo 


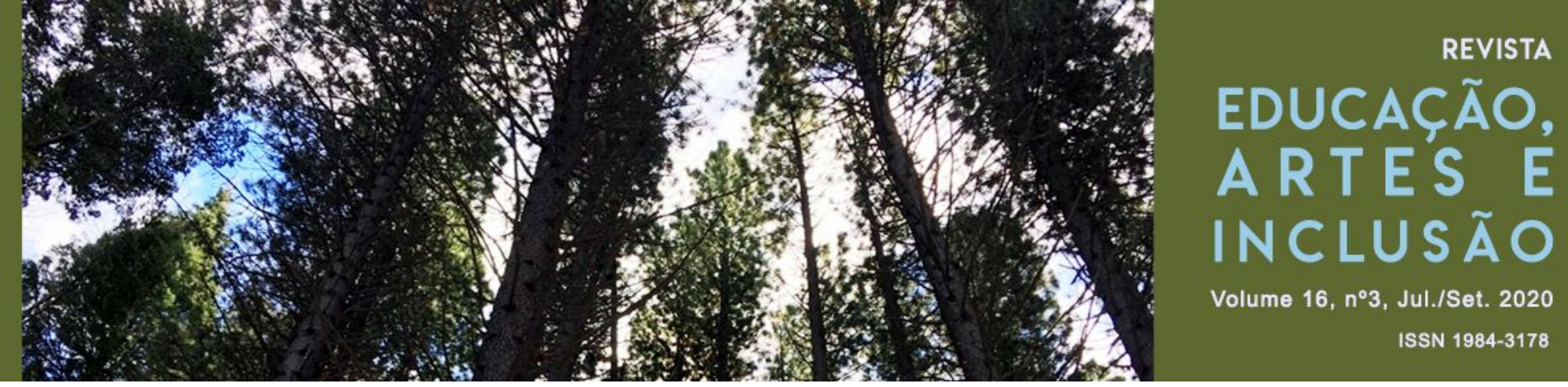

social de pessoas com deficiência visual, sendo reconhecidos como cidadãos de direitos e deveres, cabe-nos pensar em uma educação visual acessível no processo de ensino-aprendizagem. Nesse sentido, não se trata de um movimento de privar o uso de imagens com pessoas que não enxergam, mas de providenciar recursos e metodologias que possibilitem à pessoa com deficiência o acesso às informações visuais.

Nesse viés, este texto se propõe a discutir os impactos das barreiras comunicacionais impostas pela sociedade às pessoas com deficiência visual ao se priorizar o uso de produtos audiovisuais não acessíveis. Para isso, este artigo relata e analisa uma experiência com grupo focal desenvolvida em um instituto de cegos do Espírito Santo. O encontro contou com a apresentação de imagens dinâmicas e estáticas em duas condições, com e sem audiodescrição, a um grupo de pessoas cegas.

Sobre audiodescrição (AD), trabalhamos com a concepção de Motta e Romeu, que a compreendem como

[...] um recurso de acessibilidade que amplia o entendimento das pessoas com deficiência visual em eventos culturais, gravados ou ao vivo, como: peças de teatro, programas de TV, exposições, mostras, musicais, óperas, desfiles e espetáculos de dança; eventos turísticos, desportivos, pedagógicos e científicos tais como aulas, seminários, congressos, palestras, feiras e outros, por meio de informação sonora (MOTTA, ROMEU, 2010, p. 7).

Cabe destacar que o recurso da audiodescrição não consiste em uma simples concessão ou atitude solidária, uma vez que a Lei nº 10.098/2000, que estabelece normas gerais e critérios básicos para a promoção da acessibilidade das pessoas portadoras de deficiência ou com mobilidade reduzida, estabelece que:

Art. 17. O Poder Público promoverá a eliminação de barreiras na comunicação e estabelecerá mecanismos e alternativas técnicas que tornem acessíveis os sistemas de comunicação e sinalização às pessoas portadoras de deficiência sensorial e com dificuldade de comunicação, para garantir-lhes o direito de acesso à informação, à 


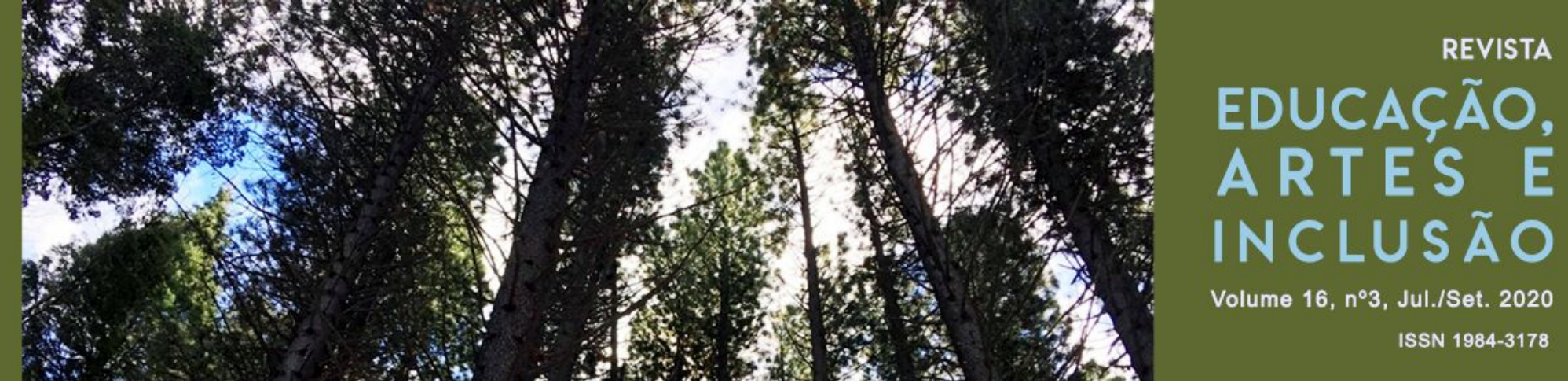

comunicação, ao trabalho, à educação, ao transporte, à cultura, ao esporte e ao lazer (BRASIL, 2000).

Tem-se, portanto, que a acessibilidade, comumente associada à construção de rampas e instalação de elevadores, ultrapassa dimensões arquitetônicas. Para Sassaki (1997, p. 42), a inclusão refere-se ao "processo pelo qual a sociedade se adapta para poder incluir as pessoas com deficiência e, simultaneamente, estas se preparam para assumir seus papéis na sociedade".

O autor cita, por exemplo: acessibilidade comunicacional (sem barreiras na comunicação interpessoal, incluindo o face-a-face, a língua de sinais, a linguagem corporal, a linguagem gestual etc.), a comunicação escrita (jornal, revista, livro, carta, apostila etc., incluindo textos em Braille, textos com letras ampliadas para quem tem baixa visão, notebook e outras tecnologias assistivas) e na comunicação virtual (acessibilidade digital); acessibilidade metodológica (sem barreiras nos métodos e técnicas de estudo, incluindo adaptações curriculares, aulas baseadas nas inteligências múltiplas, uso de todos os estilos de aprendizagem, participação do todo de cada aluno, novo conceito de avaliação de aprendizagem, novo conceito de educação, novo conceito de logística didática etc.); 4) acessibilidade instrumental (sem barreiras nos instrumentos e utensílios de estudo, como lápis, caneta, transferidor, régua, teclado de computador, materiais pedagógicos), de atividades da vida diária (tecnologia assistiva para comunicar, fazer a higiene pessoal, vestir, comer, andar, tomar banho etc.) e de lazer, esporte e recreação (dispositivos que atendam às limitações sensoriais, físicas e mentais etc.); acessibilidade programática (sem barreiras invisíveis embutidas em políticas públicas); acessibilidade atitudinal (promovida por meio de programas e práticas de sensibilização e de conscientização das pessoas em geral e da convivência na diversidade humana, resultando em quebra de preconceitos, estigmas, estereótipos e discriminações (SASSAKI, 2007, p. 23). 


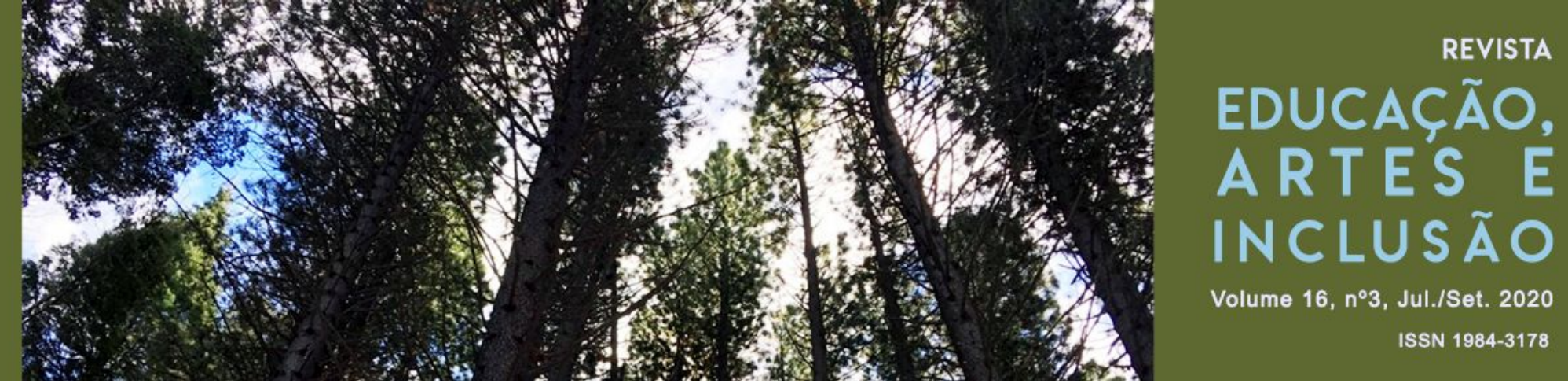

Nesse contexto, a AD integra um arsenal de recursos que visam garantir a acessibilidade comunicacional nos diversos produtos audiovisuais, sejam artísticos, educacionais, profissionais, turísticos, dentre outros, considerando que em todos esses sítios as informações são recebidas principalmente pelo canal visual, o que segrega uma parcela da população que necessita utilizar os demais sentidos para processar o conhecimento produzido nesses canais.

\section{ACESSO ÀS IMAGENS POR MEIOS NÃO VISUAIS: CAMINHOS POSSÍVEIS}

Schütz-Foerste (2004), ao discutir sobre algumas possibilidades de leitura de imagens, elenca: a imagem como intertexto, a imagem como representação, a imagem como fonte histórica e a imagem na construção identitária. Como intertexto, ela destaca que:

[...] podemos perceber, como leitores, que integramos uma complexa rede de produção, leitura e reprodução, num processo ininterrupto. A esse diálogo, que se dá na citação, dá-se o nome de intertextualidade. [...] Na produção de imagens as citações também acontecem. Uma imagem pode retornar temas, formas e/ou cores de outras. Ao estabelecer um diálogo entre imagens (textos) o artista pode reafirmar, valorizar e exaltar a outra imagem (texto) citado. Em todo o caso, a nova imagem (texto) é uma nova construção, uma nova realidade que traz consigo novos conceitos e formas (SCHÜTZ-FOERSTE, 2004, p. 52).

Percebemos isso não somente nas imagens de obras de arte, mas também nas ilustrações presentes nos livros didáticos. Figuras que podem ter função muito além da ornamental complementam e suplementam os conteúdos curriculares, além de serem utilizadas em exercícios de interpretação de texto, nos quais são ainda exigidas comparações entre imagens em busca da uma intertextualidade. Tarefas com objetivos pedagógicos bastante relevantes, todavia desafiadoras e até 


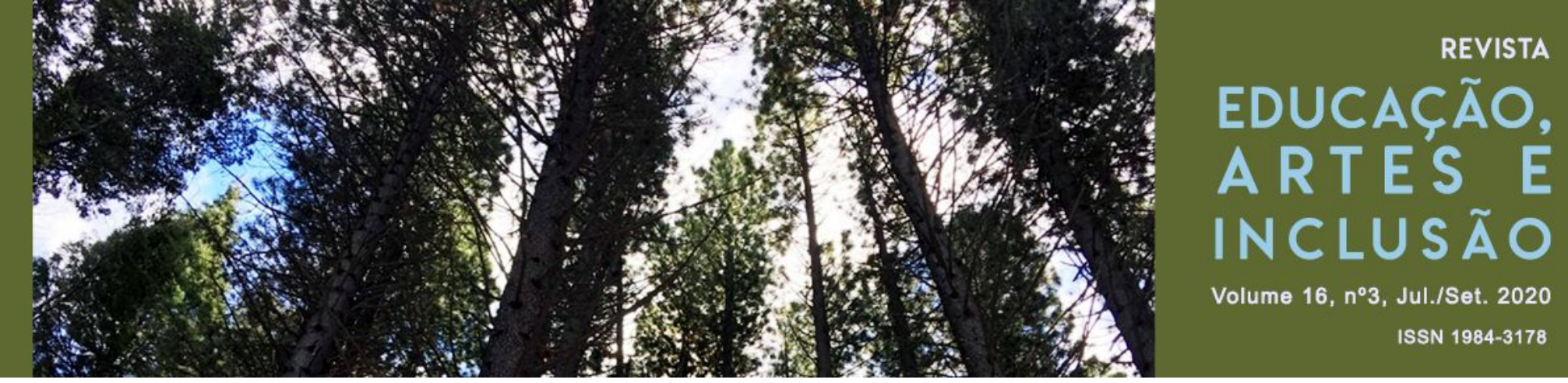

impossíveis para o leitor com deficiência visual, quando não são estudadas e atendidas as particularidades de adaptação das imagens em questão.

Koehler (2017) exemplifica, em sua tese de doutorado, que, ao fazer a transcrição de um livro didático de Língua Portuguesa em tinta para Braille, para atender a um aluno cego, precisou adaptar uma série de imagens do livro que visavam a atividades de interpretação de texto. Dentre elas estavam fotografias, imagens de obras de arte, esquemas, fluxogramas, tabelas, charges, dentre outras. Aliás, é possível notar que muitos desses livros têm se tornado mais atraentes aos estudantes justamente pela qualidade gráfica, com diversidade de cores e imagens, a partir das quais o autor propõe exercícios que incentivam a interpretação de textos verbo-visuais. A autora exemplifica uma dessas imagens:

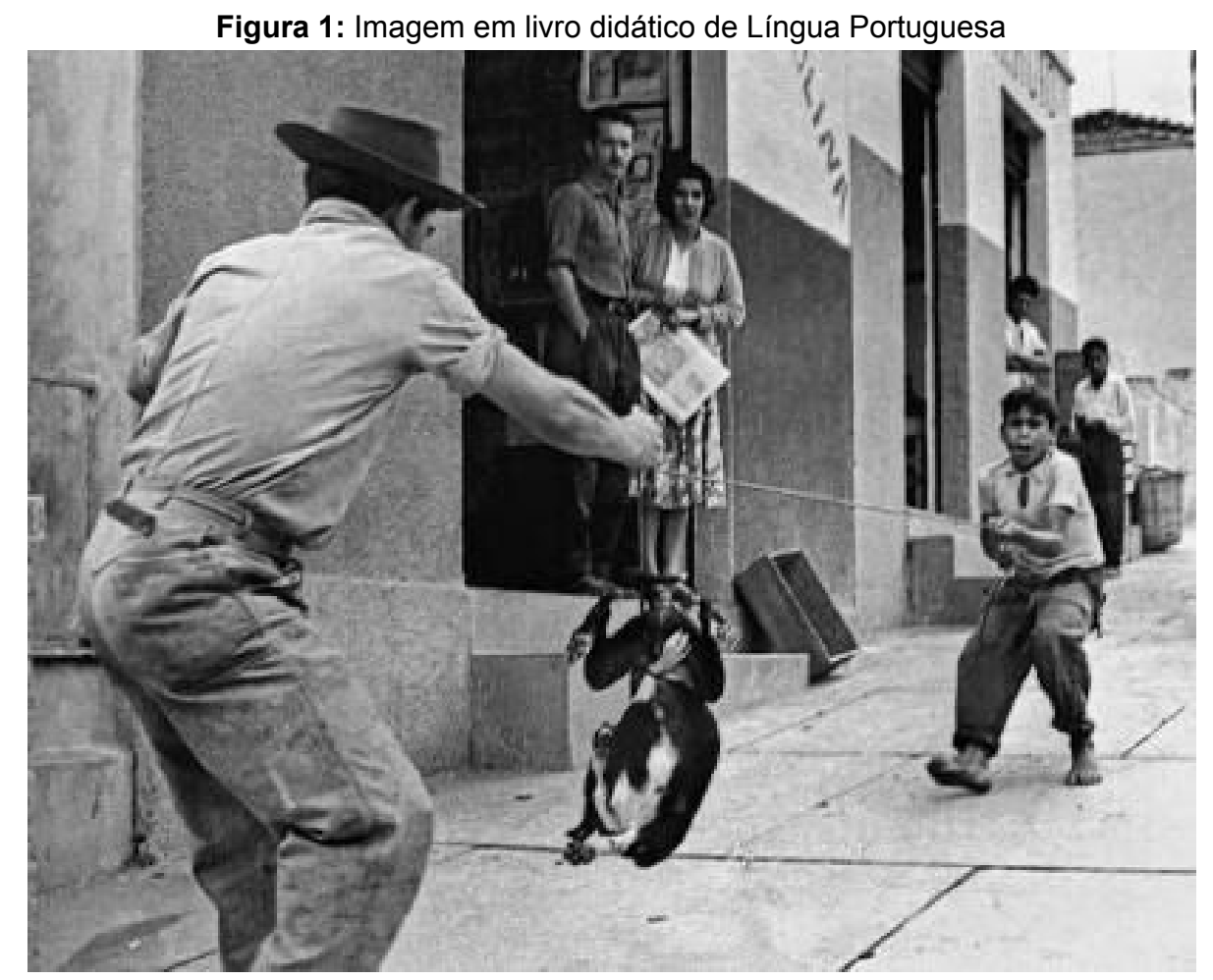

Fonte: livro Português Linguagens, $7^{\circ}$ ano, de Willian Roberto Cereja, p. 54 apud Koehler, 2017, p. 30. 


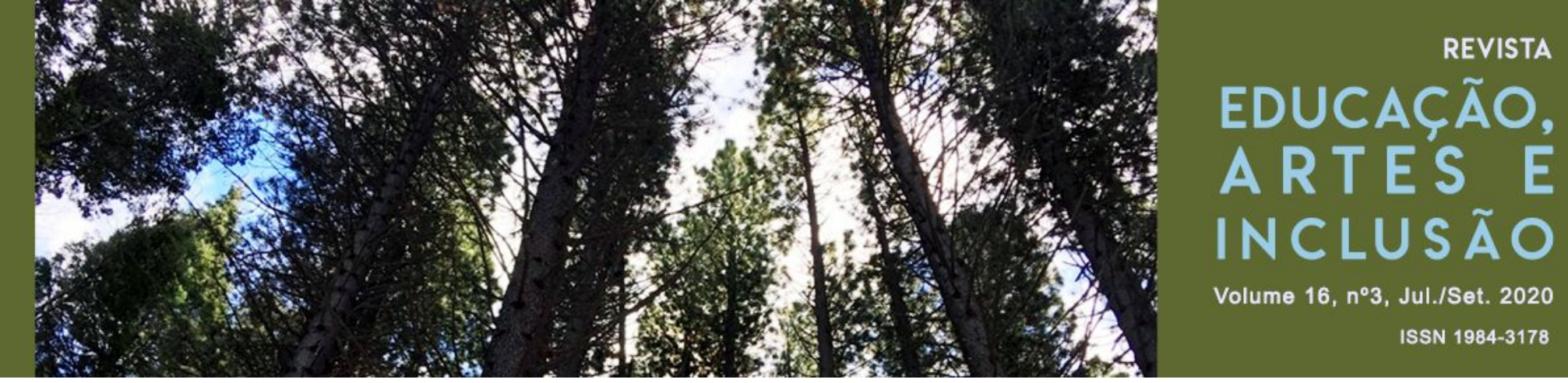

Sobre essa imagem, Koehler (2017) cita que os exercícios de interpretação de texto atrelados a ela incluíam questões do tipo:

Qual é a profissão do homem? O que ele acabou de fazer? O que o menino está tentando fazer? Observe as outras pessoas que aparecem na calçada. Elas estão interessadas na cena? O que a expressão do rosto e os movimentos do menino demonstram? (KOEHLER, p. 31).

$\mathrm{Na}$ ocasião, relatou a autora, ela teve dificuldades de elaborar uma descrição da imagem que fornecesse ao aluno os elementos necessários para que ele próprio interpretasse a fotografia e respondesse aos exercícios, sem que recebesse interpretações prontas da transcritora. Anos depois, a pesquisadora teve a oportunidade de retomar essa imagem junto a uma consultora de audiodescrição e elaborou uma descrição possível para o contexto (KOEHLER, 2017).

Sobre a imagem como representação, Schütz-Foerste (2004) faz uma distinção entre as visões platônica e aristotélica, ainda a respeito da imagem na obra de arte: primeira, vê a criação artística como simulacro ou mimésis, enquanto a segunda a concebe como realismo sublimado. Isso significa dizer que Platão atribuía somente ao criador do universo o poder de criar, enquanto o artista expressava um mundo de aparências. Por outra via, Aristóteles, seu discípulo, compreende que o artista cria e recria a realidade a partir da techné, que lhe permite selecionar e compor elementos buscando a forma mais perfeita e harmoniosa (SCHÜTZ-FOERSTE, 2004, p. 58). A imitação, pois, teria um caráter pedagógico, pois seu efeito (catarse) promoveria uma identificação com o personagem, criando ou despertando sentimentos que purificam e educam, caracterizando normas de ações. Em contraponto, como se daria a identificação com um personagem predominantemente imagético quando o leitor/espectador é uma pessoa com deficiência visual? 


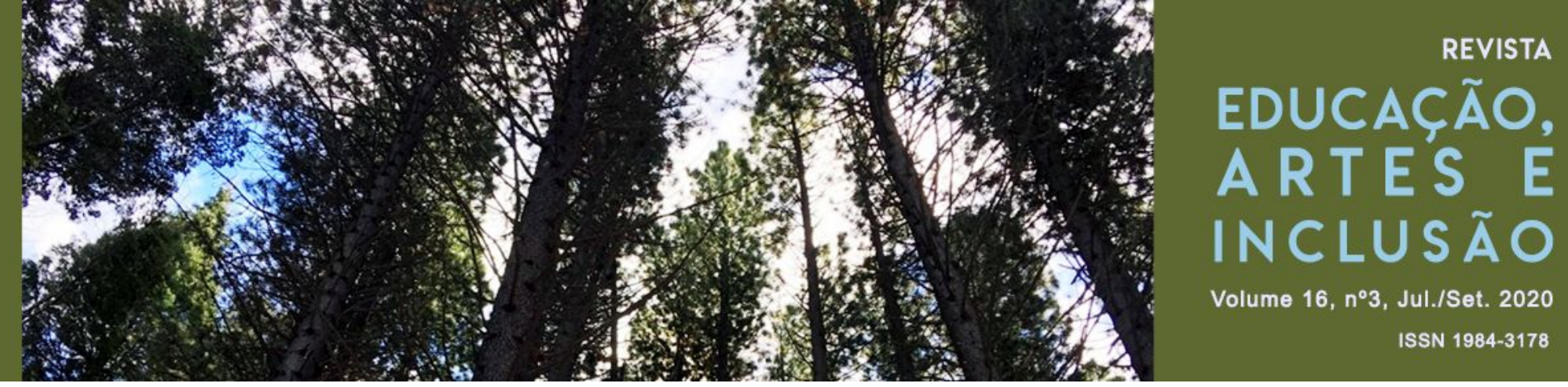

Segundo Wulf (2013), os processos miméticos remetem não apenas ao modo de se comportar com os produtos da cultura, mas aplicam-se igualmente às relações sociais, às formas de ação, às encenações e representações do social. Trata-se de formas especiais de saber prático, aprendidas de modo mimético em processos sensíveis e corporais, e que permitem agir de maneira competente em instituições e organizações. Assim, à medida que os processos miméticos remetem a produtos, cenas, arranjos e representações históricas e culturais, eles fazem parte dos processos importantes nos quais a cultura é transmitida às gerações futuras. Sem as capacidades miméticas, a aprendizagem da cultura seria impossível, bem como a dupla herança que é a transmissão dos bens culturais, que aparece em segundo lugar para os homens, depois da herança biológica, e que permite, por exemplo, uma modificação e um aprofundamento da cultura (WULF, 2013). Ele avança no sentido de que

Os processos miméticos visam o desconhecido, transformando-o, através da nova experiência, em algo conhecido. No processo mimético, ocorre uma coincidência entre uma aproximação ativa do mundo e uma integração passiva do mesmo no interior do indivíduo. A receptividade, que garante a semelhança entre os indivíduos, enquanto a atividade é responsável pela diferença entre eles. $O$ mimetismo não é simples imitação, mas produz também algo de novo. (WULF, 2013, p. 57)

Por conseguinte, se parte desse processo mimético depende das informações obtidas pelo universo imagético, ressaltamos que restringir o acesso às imagens a pessoas cegas edifica ainda mais as barreiras atitudinais e comunicacionais em uma sociedade já tão barbarizada historicamente na opressão a determinados grupos.

Retomando Schütz-Foerste, em relação à imagem como fonte histórica, ela lembra que

A imagem está presente em estudos historiográficos desde o século XIX, sua utilização, porém, restringia-se ao caráter ilustrativo. No 


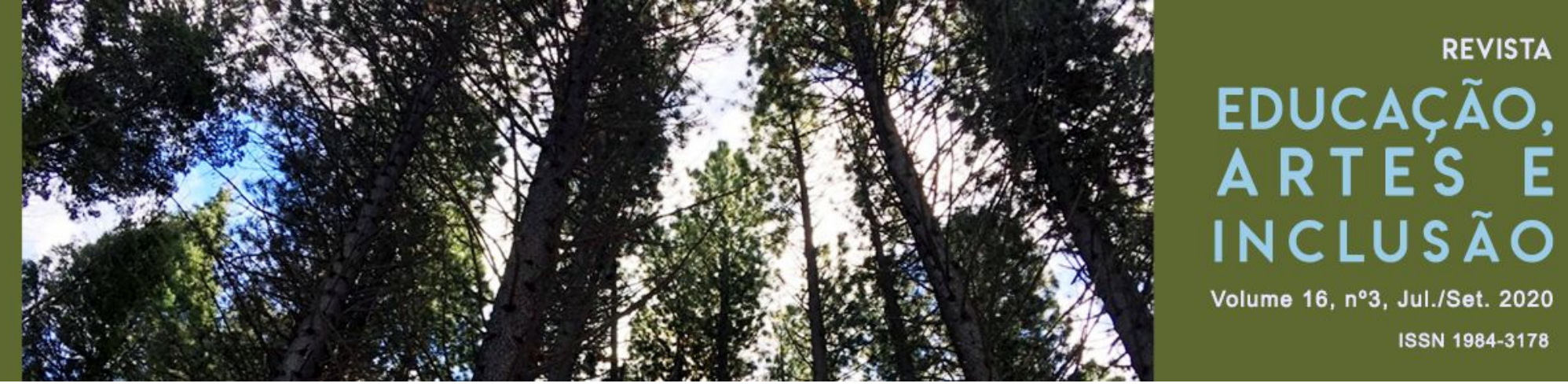

interstício de 1915 à década de 70 , pelo grande investimento em pesquisas quantitativas, prevaleceram os quadros estatísticos e gráficos, visto que estes simbolizavam o rigor matemático e conferiam maior legitimidade à pesquisa. A partir de meados dos anos 70 estudos que se valiam da fotografia como objeto de investigação receberam novo impulso (SCHÜTZ-FOERSTE, 2004, p. 61).

Em relação ao processo de produção, apropriação, preservação, utilização, observação e interpretação da imagem, a filósofa e professora Maria Ciavatta afirma que este é "permeado por elementos ideológicos da concepção de realidade e da visão de mundo de cada um dos sujeitos envolvidos" (CIAVATTA, 2012, p. 36). Assim, as imagens carregam consigo histórias, seleções, concepções e interesses que em muito ultrapassam o caráter alegórico dessas nos veículos que comunicam. Para a autora, ainda, "a imagem é sempre parte do pensamento, da linguagem, da cultura e da história vivenciada e expressa por cada um deles, salva nos vestígios de algum tempo e lugar" (CIAVATTA, 2012, p. 36). Assim, quando o acesso às imagens é limitado para um público específico, este é alijado de um direito incompressível que compromete o seu protagonismo social. Cabe destacar que as imagens também possuem o poder de legitimar discursos, como verificamos em estudos científicos e materiais didáticos que empregam textos verbo-visuais em seus conteúdos.

$\mathrm{E}$, em relação à imagem na construção identitária, a autora relembra o "silêncio histórico, a que foram submetidas muitas vozes/imagens relacionadas a grupos étnicos marginalizados na sociedade capitalista ocidental" (SCHÜTZ-FOERSTE, 2004, p. 68), referindo-se a imagens que acobertam presenças e ausências, e que precisam ser ressignificadas com um pensamento crítico que considere a multiplicidade de histórias emergidas nas vozes silenciadas e submergidas em discursos hegemônicos. Percebe-se, então, que o não acesso às 


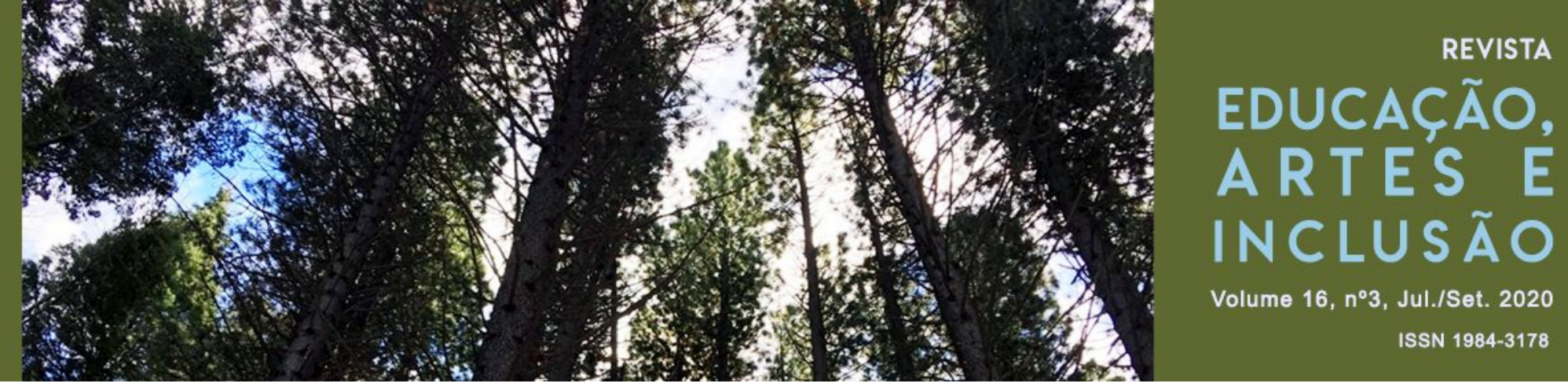

imagens implica a alienação sobre muitos acontecimentos, influências estéticas, estratégias de marketing, persuasão comercial e política ou simplesmente lazer.

Dada a relevância das imagens para todos, o que dizer das imagens para pessoas com deficiência visual? O neurologista americano Oliver Sacks, em sua obra O olhar da mente (2010), relata casos clínicos de distúrbios da memória e da visão que levaram pessoas a descobrir e inventar outras formas de ver o mundo ao redor. Oliver narra a história de Lilian Kallir, uma célebre pianista que durante uma apresentação musical surpreendeu-se ao não conseguir ler o concerto de número 21 para piano, de Mozart, pois apesar de ver as pautas e as notas, o conjunto não the fazia sentido. A atrofia detectada no córtex afetou sua visão, sua memória e sua capacidade de ler e de escrever. A memória, antes alimentada em grande parte pelos olhos, passou a ser nutrida pela audição, de forma que Lilian passou a utilizar mais esse sentido para produzir e reproduzir músicas. E, como não lia rótulos dos condimentos, passou a utilizar o olfato para identificá-los. Mudou também a sua forma de organização nos diferentes espaços:

[...] para isso usava um sistema de classificação informal em vez do conhecimento perceptual direto. Categorizava as coisas não com base no significado, mas na cor, tamanho, forma e posição; pelo contexto, por associação, mais ou menos como um analfabeto organizaria os livros numa biblioteca. Cada coisa tinha seu lugar, e Lilian memorizara isso (SACKS, 2010, p. 15).

Quando a categorização não funcionava, ela agia por tentativa e erro. Também desenvolvia mapas mentais, por exemplo, dos diversos corredores do supermercado que frequentava e usava a inferências para identificar objetos: a percepção das cores, formas, texturas e movimentos, além da memória.

Outro caso relatado por Oliver é o de John Hull, professor de ensino religioso na Inglaterra. O homem, que nasceu enxergando parcialmente, perdeu a visão em um dos olhos aos 13 anos e aos 48 perdeu a segunda. A experiência de perder a visão aos poucos deu origem ao livro Touchingthe rock: na experience of blindness, 


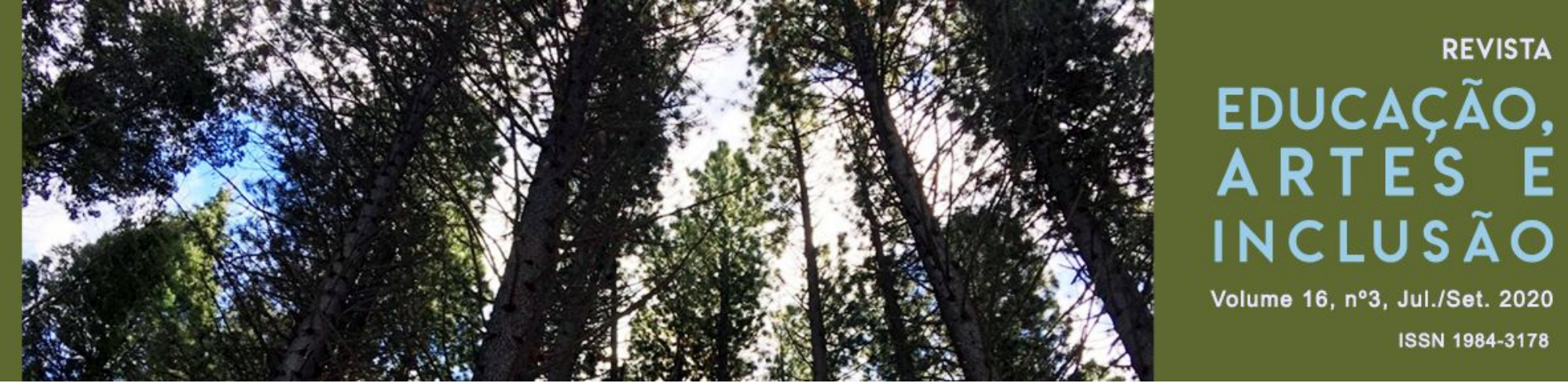

no qual Hull descreve sua redução gradual da imagética e memória visuais após ficar cego, até chegar ao ponto em que essas imagens e memórias foram extintas de sua mente, com exceção dos sonhos que tinha enquanto dormia. Segundo John, após se esquecer completamente das imagens, ele perdeu a noção do que fora um dia enxergar. Chegou inclusive a perder o entendimento de expressões como "aqui","ali" e "defronte" (SACKS, 2010, p. 201). O professor deixou de imaginar os rostos de pessoas conhecidas, bem como os objetos ao seu redor, mas sentiu a intensificação de seus outros sentidos, processo que ocorreu aproximadamente dois anos após a perda total da visão. Todavia, passado o momento de luto, ele descreve o quanto se aproximou da natureza, como alguém que vê com o corpo todo e que passara a observar detalhes dantes não percebidos:

A chuva tem um modo de revelar os contornos de tudo; joga um manto colorido sobre coisas antes invisíveis; em vez de um mundo intermitente e, portanto, fragmentado, a chuva que cai ininterruptamente cria a continuidade da sensação acústica. [...] apresenta de uma vez a totalidade de uma situação [...] dá uma ideia da perspectiva e das verdadeiras relações de uma parte do mundo com outra (HULL apud SACKS, 2010, p. 203).

E foi assim que John Hull se referia ao novo estado como uma dádiva misteriosa, paradoxal, que possibilitou a ele o redirecionamento para uma nova identidade perceptual. Assim, no caso de Hull, enquanto perdia sua capacidade visual, o seu cérebro potencializou outras funções sensitivas.

É fato que as interações sociais estão sujeitas a uma série de fatores que influenciam na condução dos processos comunicacionais. O tempo, o espaço físico, o corpo, os fatores históricos, tudo isso interage com as pessoas envolvidas e atua nas expectativas e na forma como a comunicação se sucede. A própria aparência dos enunciadores, a postura corporal e os gestos provocam expectativas que conduzem os diálogos e por vezes determinam a inclusão de indivíduos num determinado grupo. É nesse sentido que a ausência dessas informações visuais 


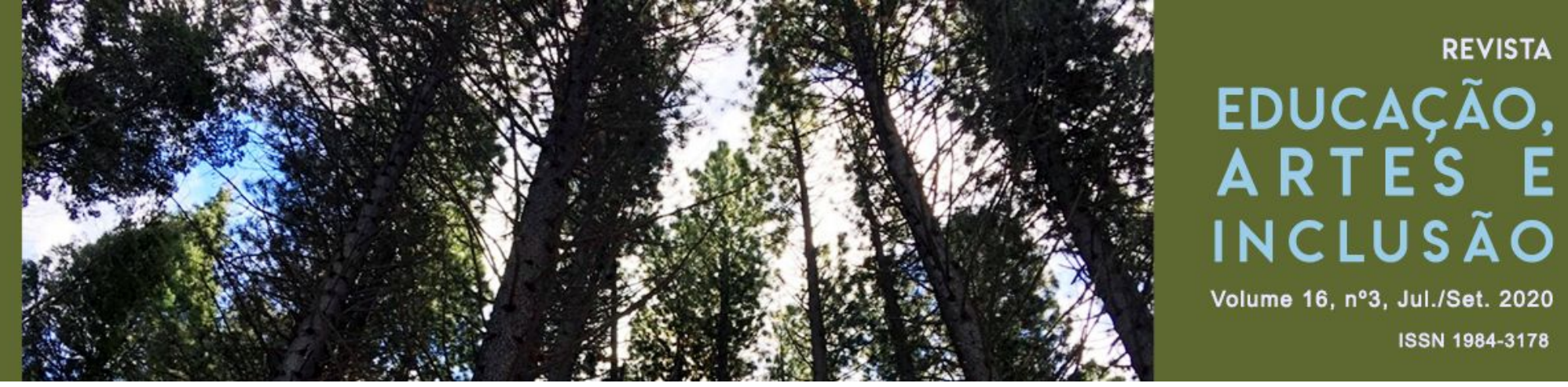

passa a constituir uma barreira comunicacional àqueles que não conseguem recebê-las visualmente.

Sob esse entendimento, foi realizado o grupo focal a fim de compreender que impactos a audiodescrição (ou a ausência dela) poderiam causar ao leitor/telespector cego quando este se propõe a consumir um produto audiovisual.

\section{O GRUPO FOCAL: IMPACTOS DAS BARREIRAS COMUNICACIONAIS EM PRODUTOS AUDIOVISUAIS}

A sessão de grupo focal aconteceu na tarde do dia 11 de julho de 2016, em um instituto de cegos do Espírito Santo, com duração de duas horas e meia, e dela participaram quatro 4 pessoas cegas, além do moderador e de mais três auxiliares responsáveis pelas anotações, gravações em vídeo e em áudio. Todos ouviram a leitura do termo de consentimento livre e esclarecido e o assinaram.

Todos os participantes cegos possuíam memórias visuais, uma vez que já enxergaram. Apesar de conviverem há anos com essa condição e de frequentarem um instituto para cegos, nenhum deles conhecia o recurso da audiodescrição.

A função do observador foi de registrar os detalhes. Chianca, citado por Gatti (2005), recomenda que esse sujeito divida o processo de observação em três etapas, a saber: abertura, em que o observador se coloca de forma a registrar o mais fielmente possível todas as informações; o desenvolvimento, no qual o grupo começa a se posicionar frente ao tema a ser desenvolvido; o fechamento, quando o grupo começa a formular uma síntese dos fenômenos ocorridos. Quanto à função do moderador, é dele a responsabilidade pelos encaminhamentos e direcionamentos necessários, bem como o incentivo na participação de todos os componentes do grupo, para que se aprofundem as discussões, possibilitando a revelação de novos aspectos e novos olhares, relativos ao tema. No transcorrer das atividades 


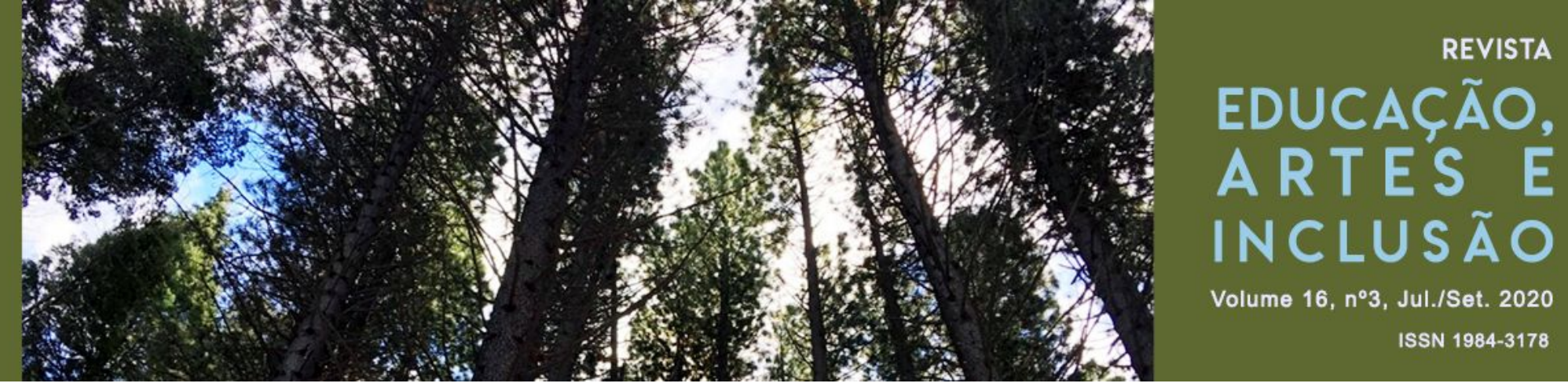

propostas houve a participação de um auxiliar de pesquisa, cuja atribuição era filmar e gravar todo o processo.

Em relação ao conteúdo, foi elaborado um roteiro de vídeos a serem transmitidos durante a sessão, com e sem audiodescrição, para que os participantes se manifestassem a respeito: a) Comercial de doação de órgãos da Santa Casa de Misericórdia (sem audiodescrição), duração de 1min7s; b) Comercial de doação de órgãos da Santa Casa de Misericórdia (com audiodescrição), duração de $1 \mathrm{~min} 7 \mathrm{~s} ; \mathrm{c}$ ) Audiodescrição de fotografia em preto e branco capturada na Guerra do Vietnã pelo francês Marc Riboud, duração de 1min; d) Audiodescrição da obra de arte Moça com brinco de pérola, do artista Jan Vermeer, duração de 30s; e) Curta-metragem Hotel Farrapos (sem audiodescrição), duração de 12min13s; f) Curta-metragem Hotel Farrapos (com audiodescrição), duração de 12min13s.

No início da sessão, todos se apresentaram e falaram um pouco de si em uma conversa informal. Nessa interlocução, foi delineado um pouco do perfil de cada um: J: tinha 39 anos, era solteiro e praticava trilhas antes de perder a visão, fato que ocorreu dois anos antes devido a atrofiamento do nervo óptico; b) N. tinha 58 anos, solteiro, perdeu a visão aos 44 devido a descolamento de retina e infecção nos olhos; mesmo cego, ele dedicava-se as aulas de inglês e informática; c) E. tinha 74 anos, casado, e contou que trabalhou como carreteiro durante 40 anos, o que foi interrompido pela perda da visão devido ao glaucoma; d) M. tinha 30 anos, era casado, fazia doces caseiros e praticava esportes adaptados para pessoas com deficiência; ele perdeu a visão aos 14 anos devido a retinopatia diabética.

A escolha dos vídeos seguiu critérios de tempo (programações curtas para que não houvesse dispersão), de temas (evitamos comerciais de marcas específicas e produções midiáticas de massa), de trilhas sonoras envolventes (uma vez que o único sentido empregado para leitura seria a audição naqueles momentos), de diversidade de gêneros textuais verbais e não verbais (propaganda, fotografia, obra 


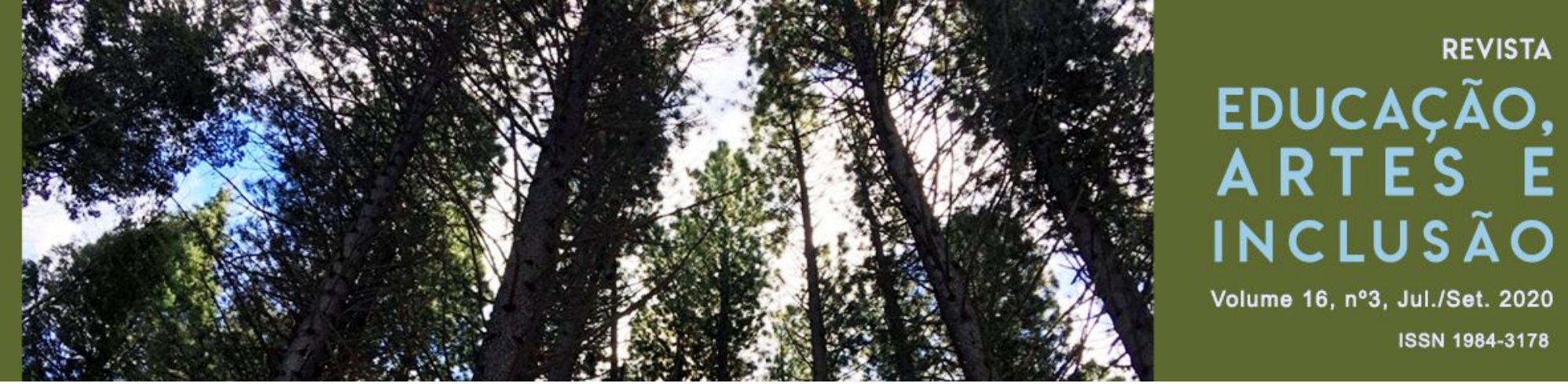

de arte e desenho de animação), e que apresentassem as versões com e sem audiodescrição.

No primeiro vídeo, "Comercial de doação de órgãos da Santa Casa de Misericórdia" (sem audiodescrição), houve dificuldade por parte dos espectadores de interpretarem o conteúdo. Houve reações como: "Tem alguma coisa a ver com um cão guia". "Tem o latido de um cachorro". "É um comercial em inglês [...] Seria um cego guiado por cachorro?"

Ao detectarmos a impossibilidade de identificarem a temática do vídeo, questionamos como seria o dia a dia deles ao assistirem a outras programações, em televisão, cinema, exposições, dentre outras. E dentre as respostas, ouvimos: "Novela mesmo tem algumas partes que dificilmente a gente consegue entender... você tem que dar continuidade... e a gente vai tentando juntar as coisas". "Olha, se tiver alguém a gente tenta perguntar ou esperar o próximo capítulo pra você juntar as coisas pra ver o desfecho". Eu só assisto noticiário normal, né [...]. Quando eu ouço falar de um acidente, aí eu tento trazer ele [...]. Aí quando é de um lugar que eu já conheço, aí eu vejo aquilo ali acontecendo."

Apenas quando foi apresentado o mesmo vídeo, porém com o recurso da audiodescrição, houve unanimidade ao dizer que o tema do comercial tratava de doação de órgãos. Os participantes também foram questionados se teriam interesse em ir a uma exposição de fotografias, ou de ver um álbum do casamento, por exemplo. Dentre as respostas, ouvimos: "Não tem sentido!" Ou "aí eu já teria uma controvérsia: depende da pessoa que vai mostrar, se ela fizer essa descrição... eu gostaria das fotografias... aqui está fulano, beltrano... aí eu consigo montar [uma imagem mental]".

Em seguida, foi transmitido o vídeo "Audiodescrição de fotografia em preto e branco capturada na Guerra do Vietnã pelo francês Marc Riboud”. Após ouvirem a audiodescrição, os participantes descreveram a imagem com detalhes, utilizando-se 


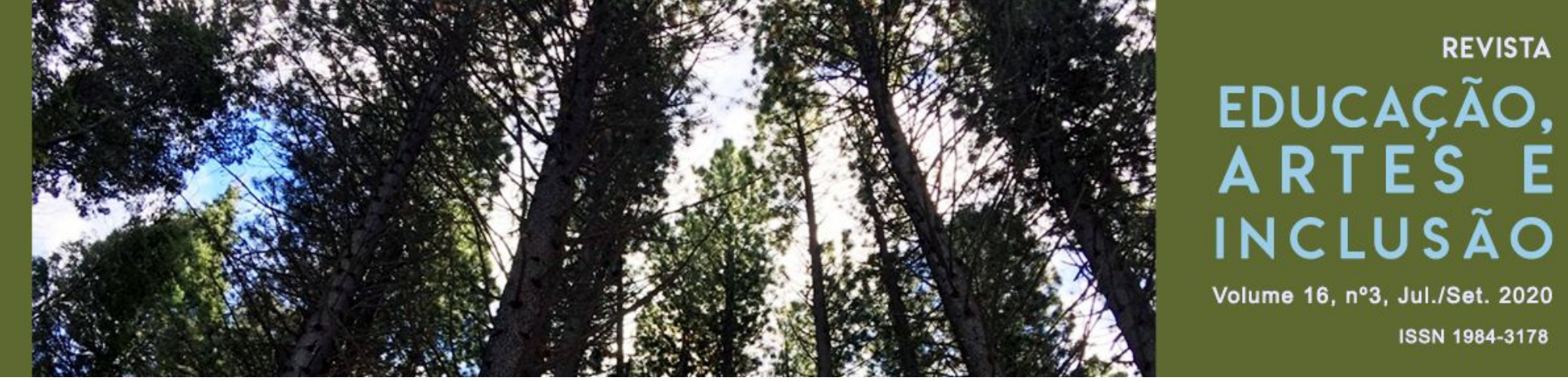

de fragmentos das informações ouvidas no vídeo. Quando questionados a respeito das expressões "primeiro plano" e "segundo plano", citadas no áudio, eles se demonstraram esclarecidos: "Fica [claro]... um se sobressaiu... um ta lá na frente e outra ta lá no fundo [...]".

Figura 2: RIBOUD, M. (fotografia) 1967. Manifestante pede paz no Vietnã

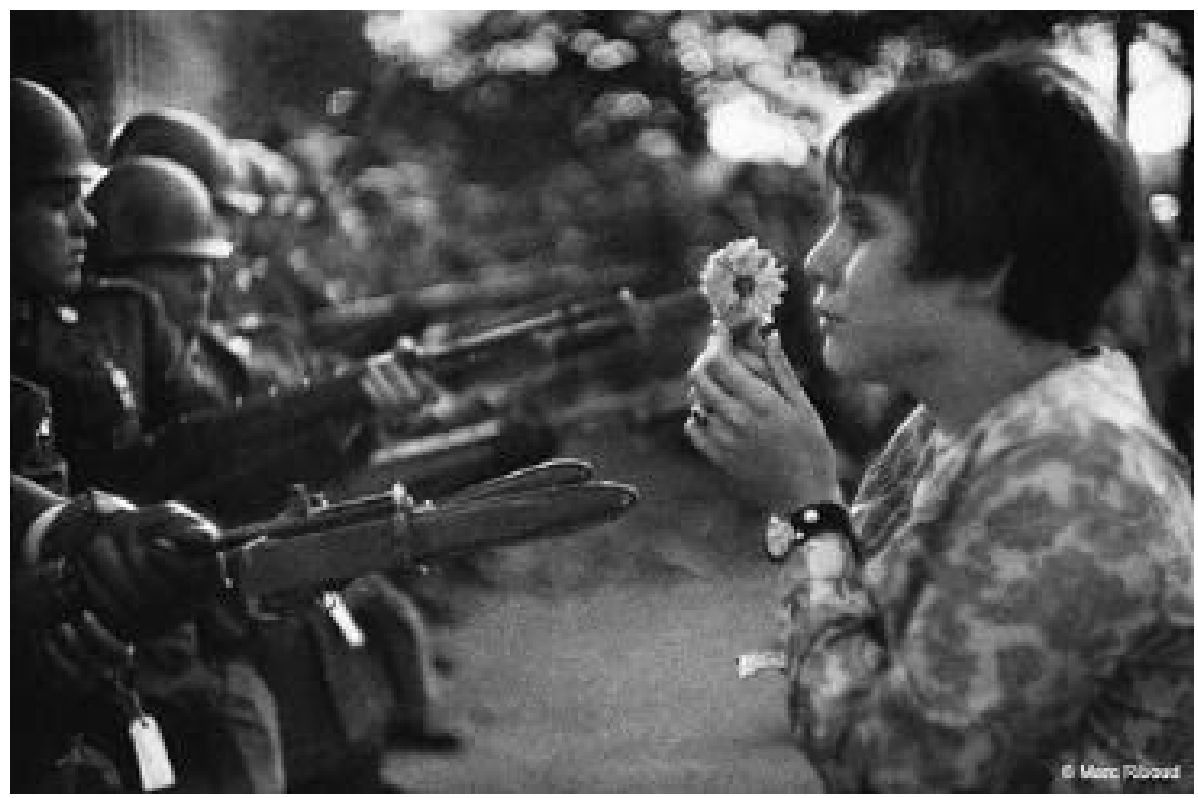

Fonte: Reprodução/ https://www.classphoto.es/blog/fotografos-zaragozala-fotografia-de-la-paz-y-el-amor/

Em sequência, foi reproduzido o vídeo "Audiodescrição da obra de arte Moça com brinco de pérola, do artista Jan Vermeer". Os participantes foram capazes de descrever o rosto virado para o lado, a pele clara, os olhos arredondados, o casaco marrom escuro com gola branca. Eles também foram unânimes em dizer que gostariam de ir a uma exposição em que houvesse descrição das imagens. 


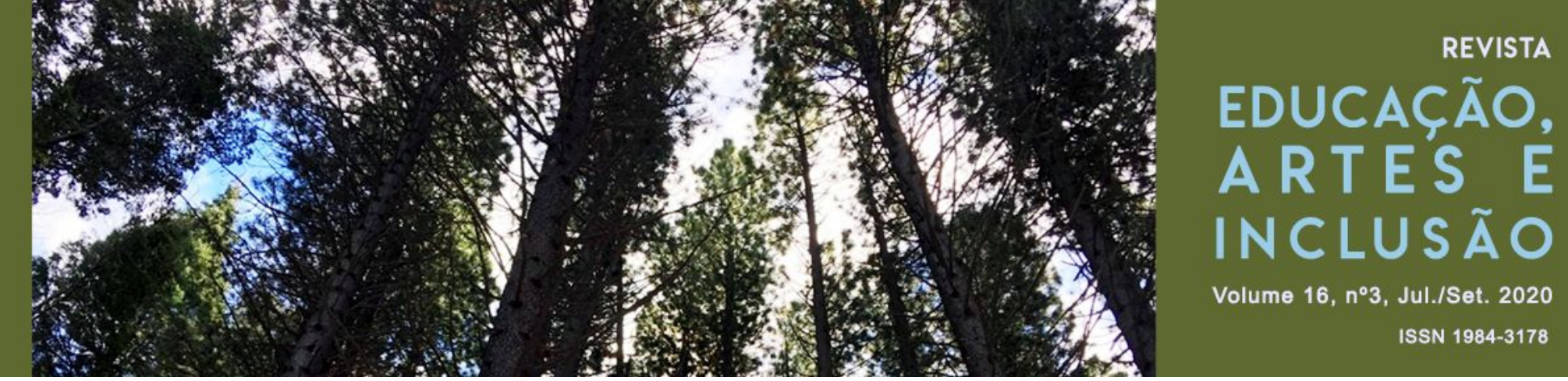

Figura 3: WERMEER, Jan. (pintura) 1665. Moça com brinco de pérola

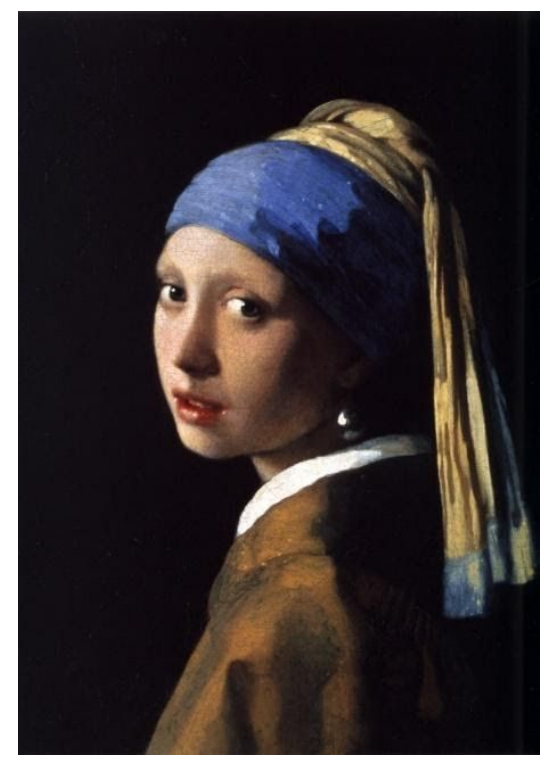

Fonte: virusdaarte.net

Dando continuidade, foi exibido o curta metragem de animação "Hotel Farrapos", sem audiodescrição. Por se tratar de um vídeo mais longo (10 minutos), sem acessibilidade, notamos que aos cinco minutos dois participantes já faziam expressões de tédio e sono. Ao fim, questionarmos o que conseguiram entender do vídeo, ficou claro que apenas alguns trechos foram captados: "Um cara saiu da cidade dele, né? Foi lá receber um dinheiro com alguém... a pessoa não tinha o dinheiro. Deu um cheque a ele [...], ele saiu até uma agência pra tentar trocar". Mas ninguém entendera o desenrolar da história desse ponto em diante.

Por fim, foi exibido o mesmo vídeo, com o adicional da audiodescrição. Ao longo da apresentação, os espectadores esboçaram sorrisos ao serem surpreendidos em algumas cenas que haviam interpretado de forma bem diferente do que ocorria de fato: "Nossa, eu nunca iria imaginar que ele tinha se encrencado com a polícia! Mudou totalmente a história que eu tinha imaginado!"

Foi notório que a interação com os produtos audiovisuais adaptados com audiodescrição ocorreu mais pontualmente, sem dispersão, e os espectadores 


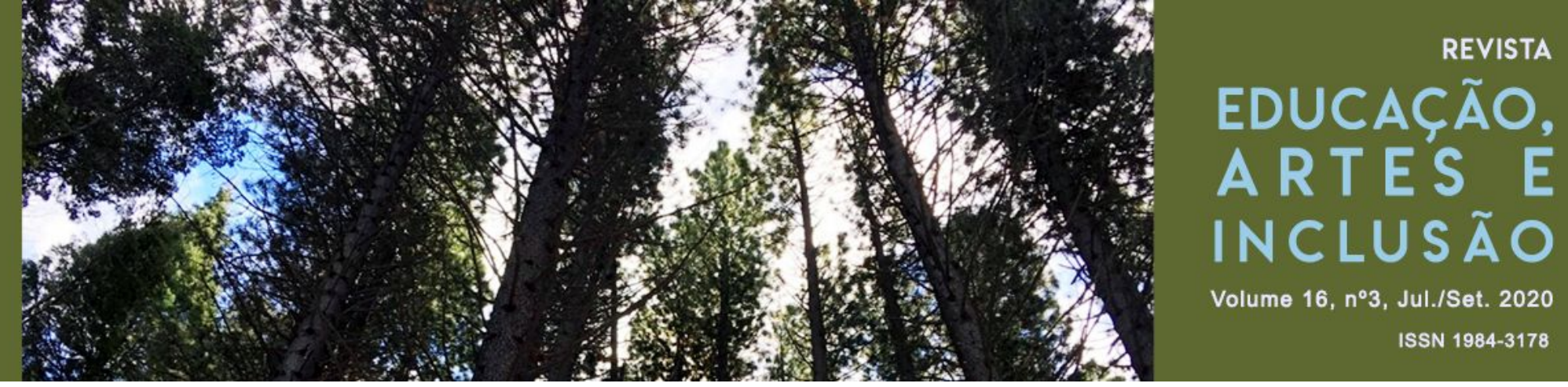

dialogaram entre si sobre detalhes visuais dos vídeos. As leituras que faziam aleatoriamente, antes da AD e sem auxílio de pessoas, pouco ou nada condiziam com as possibilidades de interpretação que as imagens ofereciam.

Com esses diálogos, reforçamos que, apesar de haver leis que asseguram o recurso da $A D$ em produtos e eventos audiovisuais, além de muitas publicações acadêmicas sobre a importância e a eficácia dela, ainda há pouco conhecimento e acesso à $A D$ entre pessoas a quem se destina esse recurso.

Felipe Leão Mianes, em sua tese de doutorado "Marcas de identificação em narrativas autobiográficas de pessoas com deficiência visual" (2015), cita a influência do mercado na produção e no consumo de identidades:

O mercado é parte importante no que tange aos processos de produção e consumo de identidades, que entre tantas formas de construção, tem na cultura um de seus pilares. Por isso mesmo, além da consolidação de direitos, a inclusão escolar incentiva o acesso a produtos culturais por pessoas com deficiência visual. Então, mais do que não excluir, é preciso fomentar o desejo de estar incluído (MIANES, 2015, p. 77).

O autor ainda complementa que "o imperativo da inclusão se configura como algo que já faz parte de quase toda a sociedade, seja pelos direitos culturais, pelo acesso à escola ou ao mercado de trabalho" e que "É difícil encontrar nos discursos atuais alguém que se oponha à inclusão, pois, os modelos ainda podem ser questionados por muitos grupos ou indivíduos, mas seu mérito permanece quase plenamente preservado" (MIANES, 2015, p. 79). Entretanto, apesar da unanimidade de que incluir é necessário, em situações práticas cotidianas ainda percebemos a pessoa com deficiência driblando restrições de acessibilidade impostas pela sociedade. 


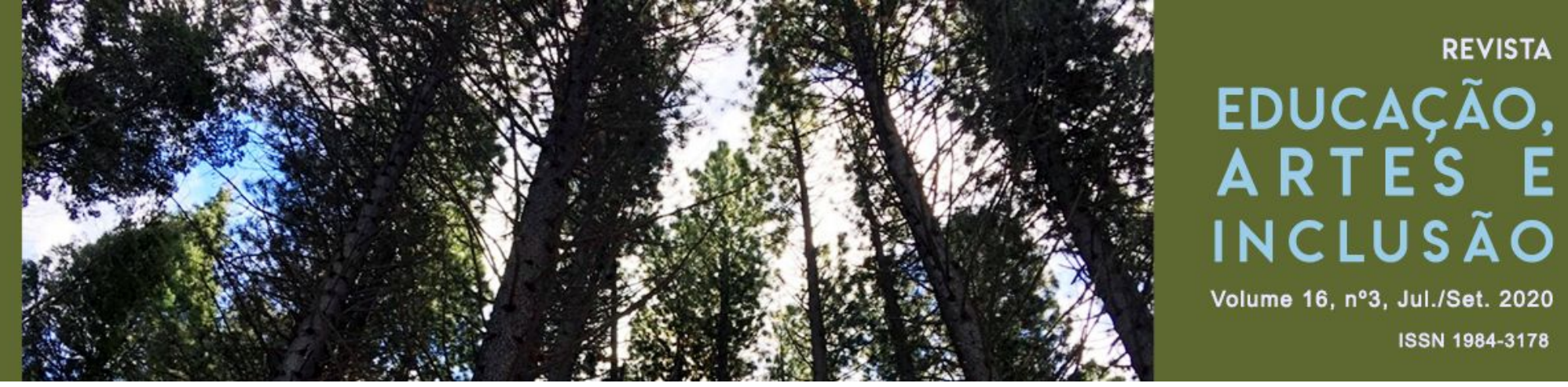

\section{CONSIDERAÇÕES}

Estimando a importância das imagens para nossa sociedade, tanto como intertexto, representação, fonte histórica quanto na construção identitária de cada sujeito, percebemos que os impactos das barreiras comunicacionais impostas pela ausência de informações visuais a pessoas cegas vão da restrição ao consumo de produtos audiovisuais de lazer aos de fins educacionais, culturais e informativos.

Fica notório que a associação da palavra acessibilidade apenas a dimensões arquitetônicas limita a grandeza do que esse termo inclui e oculta outras interfaces que precisam ser consideradas: comunicacional, metodológica, instrumental, programática e atitudinal, conforme aponta Sassaki (2007).

A audiodescrição integra um arsenal de recursos que visam garantir a acessibilidade comunicacional nos diversos produtos audiovisuais, sejam artísticos, educacionais, profissionais, turísticos, dentre outros, contribuindo para a promoção de uma educação visual acessível a pessoas com deficiência visual.

A ausência da $A D$ nesses produtos, portanto, impõe limitações à formação desse público leitor no que diz respeito ao texto imagético como intertexto, representação e fonte histórica, o que influencia diretamente na construção identitária dos sujeitos que compõem esse grupo. Ademais, a escassa experiência com processos miméticos que remetem a produtos, cenas, arranjos e representações históricas e culturais, por parte desse público, pode limitar ainda a aquisição e a transmissão de bens culturais entre gerações desse mesmo grupo.

\section{REFERÊNCIAS}

BAKHTIN. M. Estética da criação verbal. São Paulo: Martins Fontes, 2003.

CAMARGO, Isaac Antonio. Domínios da Imagem. Londrina, V. I, N. 1, p. 111-118, nov. 2007. 
